University of Nebraska - Lincoln

DigitalCommons@University of Nebraska - Lincoln

\title{
Performance and Potential of Intergeneric Wheatgrass Hybrids in the Central Great Plains
}

\author{
Kenneth P. Vogel \\ University of Nebraska-Lincoln, kvogel1@unl.edu \\ H. G. Jung \\ USDA-ARS \\ P. E. Reece \\ University of Nebraska-Lincoln, preece1@unl.edu
}

Follow this and additional works at: https://digitalcommons.unl.edu/usdaarsfacpub

Vogel, Kenneth P.; Jung, H. G.; and Reece, P. E., "Performance and Potential of Intergeneric Wheatgrass Hybrids in the Central Great Plains" (1987). Publications from USDA-ARS / UNL Faculty. 1888.

https://digitalcommons.unl.edu/usdaarsfacpub/1888

This Article is brought to you for free and open access by the U.S. Department of Agriculture: Agricultural Research Service, Lincoln, Nebraska at DigitalCommons@University of Nebraska - Lincoln. It has been accepted for inclusion in Publications from USDA-ARS / UNL Faculty by an authorized administrator of DigitalCommons@University of Nebraska - Lincoln. 


\title{
Performance and Potential of Intergeneric Wheatgrass Hybrids in the Central Great Plains ${ }^{1}$
}

\author{
K. P. Vogel, H. G. Jung, and P. E. Reece ${ }^{2}$
}

\begin{abstract}
Three studies were conducted to evaluate intergeneric wheatgrass hybrids for their potential as range and pasture grasses in the Central Great Plains. Quackgrass [Elytriga repens $(\mathrm{L}$.) Nevski] $X$ bluebunch wheatgrass [Psueodoroegneria spicata (Pursh) $\boldsymbol{A}$. Love] $\boldsymbol{F}_{5}$ hybrid lines (RS lines) developed by D.R. Dewey were grown in a space transplanted nursery at Lincoln, NE, to estimate genetic variability for forage yield and quality as measured by in vitro dry matter digestibility (IVDMD) and protein in the RS population. There was significant variability among the RS lines for all traits (broad-sense heritability $H>0.5)$ except for first harvest IVDMD $(H=0.26)$. The highest yielding RS lines yielded only about half as much forage as 'Slate' intermediate wheatgrass [Thinopyron intermedium (Host) Barkworth and D.R. Dewey subsp. intermedium], which was included as a check. Slate intermediate wheatgrass, 'Ruff' crested wheatgrass [Agropyron cristatum (L.) Gaertner], 'Nordan' crested wheatgrass $[A$. desertorum (Fisch.) Schultes], RS-1 and RS-2 (quackgrass $\times$ bluebunch wheatgrass germplasm), and a quackgrass $\times A$. desertorum hybrid designated as RD were then evaluated in sward nurseries in two environments (Mead and Alliance, NE) that differ widely in climate. Intermediate wheatgrass was clearly superior in forage yield and quality as measured by IVDMD in the eastern part (Mead) of the Central Great Plains. In the western part of this area (Alliance) intermediate and the crested wheatgrasses were equal or superior to the RS hybrids in forage yield and intermediate wheatgrass had higher IVDMD. The RD hybrid had lower yields than the other strains at both locations. Yields of the intergeneric wheatgrass hybrids could be improved by breeding to make them more competitive with intermediate and crested wheatgrasses. The same breeding effort could be used to improve these pure species for which substantial genetic variability for both yield and IVDMD has been previously documented and would probably result in greater overall progress. Forages from grasses grown at Mead in swards were analyzed using the detergent system of analyses and there was considerable variation among the grasses in fiber composition and digestibility of the fiber components even though the grasses were very similar in physiological maturity when harvested. The results suggest that there are genetic differences among these wheatgrasses in forage fiber composition and the digestibility of the fiber components.
\end{abstract}

Additional index words: Agropyron repens (L.) Beauv., Agropyron desertorum (Fisch) Schultes, Agropyron cristatum (L.) Gaertner, Agropyron spicatum (Pursh) Schrib. and Smith, Agropyron intermedium (Host) Beauv., Elytrigia repens (L.) Nevski, Pseudoroegneria spicata (Pursh) Love, Thinopyron intermedium (Host) Barkworth and D.R. Dewey, Forage yield, Forage quality, In vitro dry matter digestibility, Fiber composition, Fiber digestibility.

$\mathrm{S}$ EVERAL intergeneric wheatgrass hybrids developed by Douglas R. Dewey at the USDA-ARS Crops Research Laboratory at Logan, UT, have shown considerable potential as forage grasses in Utah (Asay and Hanson, 1984; Perez-Trejo et al., 1979; Gomm
Table 1. Common names and traditional and proposed Latin binominals of the wheatgrasses and the intergeneric-hybrids evaluated.

\begin{tabular}{|c|c|c|}
\hline $\begin{array}{c}\text { Common name } \\
\text { (Hitchcock, } \\
\text { 1951) }\end{array}$ & $\begin{array}{c}\text { Traditional Latin } \\
\text { binominal } \\
\text { (Hitchcock, 1951) }\end{array}$ & $\begin{array}{l}\text { Proposed Latin } \\
\text { binominal (Barkworth } \\
\text { and Dewey, 1985) }\end{array}$ \\
\hline Quackgrass & $\begin{array}{l}\text { Agropyron repens (L.) } \\
\text { Beauv. }\end{array}$ & $\begin{array}{l}\text { Elytrigia repens (L.) } \\
\text { Nevski }\end{array}$ \\
\hline $\begin{array}{l}\text { Bluebunch } \\
\text { wheatgrass }\end{array}$ & $\begin{array}{l}A \text {. spicatum (Pursh) Schrib. } \\
\text { and Smith }\end{array}$ & $\begin{array}{l}\text { Pseuodoroegneria } \\
\text { spicata (Pursh) Love }\end{array}$ \\
\hline $\begin{array}{l}\text { Standard crested } \\
\text { wheatgrass }\end{array}$ & $\begin{array}{l}\text { A. desertorum (Fisch.) } \\
\text { Schultes }\end{array}$ & $\begin{array}{l}\text { A. desertorum (Fisch. } \\
\text { ex Link) Schultes }\end{array}$ \\
\hline $\begin{array}{l}\text { Fairway crested } \\
\text { wheatgrass }\end{array}$ & A. cristatum (L.) Gaertner & $\begin{array}{l}\text { A. cristatum (L.) } \\
\text { Gaertner }\end{array}$ \\
\hline $\begin{array}{l}\text { Intermediate } \\
\text { wheatgrass }\end{array}$ & $\begin{array}{l}\text { A. intermedium (Host) } \\
\text { Beauv. }\end{array}$ & $\begin{array}{l}\text { Thinopyron } \\
\text { intermedium (Host) } \\
\text { Barkworth and } \\
\text { D.R. Dewey }\end{array}$ \\
\hline
\end{tabular}

and Horton, 1983). The purpose of this study was to evaluate the most promising intergeneric wheatgrass hybrids for their potential as range and pasture grasses in the Central Great Plains. Because the wheatgrass nomenclature is currently unresolved, the common names and the traditional (Hitchcock, 1951) and proposed (Dewey, 1984; Barkworth and Dewey, 1985) Latin binominals for the parental species of the intergeneric hybrids and the other grasses evaluated in this study are listed in Table 1 .

The most promising intergeneric hybrids have been those involving quackgrass (Dewey, 1980). The intergeneric hybrids evaluated in this study are the quackgrass $X$ bluebunch wheatgrass (RS for repens $X$ spicatum) hybrids and the quackgrass $X$ standard crested wheatgrass ( $R D$ for repens $\times$ desertorum) hybrids. The derivation of these hybrids has been well documented by Dewey $(1961,1976)$.

The potential for improving the RS population by breeding was examined in a replicated study of lines

'Contribution of USDA-ARS and the Nebraska Agric. Res. Division. Published as paper no. 7990, Journal Series, Nebraska Agric. Res. Division. Received 3 Feb. 1986

${ }^{2}$ Supervisory research geneticist, USDA-ARS, Dep. of Agronomy, Univ. of Nebraska, Lincoln, NE 68583; research animal scientist, USDA-ARS, U.S. Meat Animal Res. Ctr., P.O. Box 166, Clay Center, NE 68933; and assistant professor, Dep. of Agronomy, Univ. of Nebraska, 4502 Avenue I, Panhandle Res. and Ext. Ctr. Scottsbluff, NE 69361 .

Published in Crop Sci. 27:8-13 (1987). 
from the RS population to estimate the genetic variability for forage yield and quality in this population (Exp. 1). The performance of the RS and RD intergeneric hybrids as measured by forage yield and quality were then compared with that of released cultivars of intermediate and crested wheatgrasses in sward nurseries at two locations in the Central Great Plains (Exp. 2) to validate the results of the space-planted nursery. The most widely grown wheatgrasses in the Central Great Plains are intermediate and crested wheatgrass. The fiber composition and the digestibility of the cell wall components of the grasses in Exp. 2 also were quantified to determine if differences existed among these wheatgrasses in forage fiber composition and the digestibility of fiber components (Exp. 3).

\section{MATERIALS AND METHODS}

\section{Experiment 1-Genetic Variability in the RS Population}

The initial experiment in this study was an evaluation of $24 F_{5}$ and $4 F_{4}$ or $F_{3}$ lines of the RS hybrid that were obtained from D.R. Dewey. The derivation of these lines was described by Dewey (1976) and Asay and Dewey (1981). Basically, they represented the fifth generation of lines selected for fertility and intermated by open-pollination each generation after the initial cross.

Individual seedlings of the RS lines, two quackgrass accessions obtained from the USDA-ARS Plant Introduction Station at Pullman, WA, and 'Slate' intermediate wheatgrass were grown in plastic seedling tubes $(22-\mathrm{cm}$ deep and $4 \mathrm{~cm}$ in diam) from January to May 1979 in a greenhouse. The seedlings were transplanted into a Kennebic soil (fine-silty, mixed, mesic Cumulic Hapludoll) located at the University of Nebraska East Campus at Lincoln, NE, on 7 May 1979. The experimental design was a randomized complete block with four replications. Plots were single row plots with 10 plants per plot. Rows and plants within rows were spaced $1.1-\mathrm{m}$ apart. The nursery was surrounded by a row of border plants. The herbicides Dacthal $=$ DCPA $=($ dimethyl tetrachloroterepthalate), and 2,4-D [(2,4-dichlorophenoxy) ácetic acid] along with cultivation and hand weeding were used in the establishment and succeeding years for weed control in this and the subsequent sward study. Rates and dates of applications were based on recommendations for this area and can be obtained from the authors. No data were collected the establishment year.

In 1980 and 1981, the nursery was mowed during the first part of April to remove the previous year's growth and was then cultivated to trim all plants to a uniform size of approximately $0.25 \mathrm{~m}^{2}$. The nursery was fertilized with 100 , 112 , and $90 \mathrm{~kg} \mathrm{ha}^{-1} \mathrm{~N}$ in September 1979, April 1980, and April 1981, respectively.

First-cut harvests of forage were made on 16 June 1980 and 24 June 1981, which was 2 and 3 weeks after all RS plants in the nursery had headed. Second-cut harvest was on 11 Nov. 1980 after a heavy frost had ended the growing season. Second-cut harvest data from 1981 were discarded because many of the RS plants were dead or they had poor yields. These problems were believed to be due to crown and root rot caused by Helminthosporium or Fusarium spp. Plots were harvested with a flail-type forage harvester to a uniform cutting height of $15 \mathrm{~cm}$. Days to heading were reported as days since the beginning of the calendar year when the majority of spikes had emerged from the boot of individual plants.
Subsamples for determination of dry matter, protein, and in vitro dry matter digestibility (IVDMD) consisted of approximately $200 \mathrm{~g}$ of freshly harvested forage that was collected and weighed in the field, dried in a forced-air oven at $65^{\circ} \mathrm{C}$, and reweighed to determine dry matter content. Dry matter content was determined and yields were calculated on a dry matter basis. Dried samples were ground in a Wiley mill to pass a $1-\mathrm{mm}$ screen. The Tilley and Terry (1963) procedure with minor modifications $\left(\mathrm{HgCl}_{2}\right.$ and $\mathrm{N}_{2} \mathrm{CO}_{3}$ were not added after the first stage digestion) was used to determine IVDMD, while the Kjeldahl procedure (AOAC, 1960) was used to determine $\mathrm{N}$ concentration. Crude protein was calculated by multiplying Kjeldahl N concentration by 6.25 .

To simplify comparisons among strains and to compensate for missing plants, all results were expressed and analyzed as individual plant means per plot. The data were analyzed as a split-plot in time with the check strains, Slate and the two quackgrasses, included to obtain statistics for mean comparisons and then without the checks to obtain estimates of variance components that were used to calculate heritability estimates. All effects were considered to be random. Approximate $F$ tests (Snedecor and Cochran, 1967, p. 364-375) were used to test the strain component of variance for both sets of analyses.

During the $3 \mathrm{yr}$ of this experiment (1979-1981), mean annual precipitation and temperature at Lincoln were 621 $\mathrm{mm}$ and $11.1^{\circ} \mathrm{C}$, respectively (National Oceanic and Atmospheric Administration, 1979-1983). Lincoln has an altitude of $351 \mathrm{~m}$ and an average growing season of 160 days.

\section{Experiment 2-Sward Evaluation of RS and RD Hybrids}

This study was conducted near Mead and Alliance, NE. Alliance is located approximately $540 \mathrm{~km}$ west of Lincoln at about the same latitude. The University of Nebraska Agricultural Research and Development Center at Mead is about $40 \mathrm{~km}$ north of Lincoln. The Mead and Alliance experiments were located on a Sharpsburg soil (silty clay Typic Argiudoll) and a Keith soil (fine-silty, mixed, mesic Aridic Argiustoll), respectively. During this experiment (1981-1983) the climatic variables for Mead vs. Alliance were as follows: annual precipitation 813 vs. $424 \mathrm{~mm}$; average annual temperature 10.5 vs. $8.4^{\circ} \mathrm{C}$; growing season 149 vs. 128 days (National Oceanic and Atmospheric Administration, 1979-1983). The elevations at Mead and Alliance are 360 and $1225 \mathrm{~m}$, respectively.

Grasses evaluated in this study are listed in Table 4. RS1 and RS-2 are $F_{8}$ RS wheatgrass germplasm releases (Asay and Dewey 1981). The quackgrass $X$ standard crested wheatgrass hybrid (RD) was obtained from K.H. Asay at the Crops Research Laboratory at Logan, UT. 'Ruff' is a fairway crested wheatgrass while 'Nordan' is a standard crested wheatgrass. Only a limited quantity of the RD seed was available. Sward plots were developed by transplanting seedlings of these grasses into plots. Seedlings were grown in small plastic seedling tubes (12-cm deep and $2.5 \mathrm{~cm}$ in diam. at the top) during the winter of 1981. They were transplanted into field plots during mid-May at both locations. The sward plots consisted of three rows of transplanted seedlings with 15 seedlings per row with seedlings and rows spaced $30-\mathrm{cm}$ apart. This stand density is equivalent to 10 plants $\mathrm{m}^{-2}$, which is considered to be a fully acceptable stand for grasses in the Great Plains (Launchbaugh, 1966). Since these grasses differ widely in degree of rhizomatous spread, a buffer row of Ruff crested wheatgrass, which is strongly caespitose, was transplanted around each individual plot. This buffer row kept the grasses from invading adjacent plots. The experimental design was 
a randomized complete block with six replications at Mead and five replications at Alliance.

The plots were fertilized after transplanting and in the spring of each succeeding year. The rates of fertilization (expressed as $\mathrm{kg} \mathrm{ha}^{-1}$ ) were as follows for Mead: $76 \mathrm{~N}$ in 1981, $100 \mathrm{~N}$ and $38 \mathrm{P}$ in 1982 , and $120 \mathrm{~N}$ and $4 \mathrm{P}$ in 1983; and for Alliance: $91 \mathrm{~N}$ and $10 \mathrm{P}$ in $1981,45 \mathrm{~N}$ and $20 \mathrm{P}$ in 1982 , and $45 \mathrm{~N}$ and $10 \mathrm{P}$ in 1983.

The plots were allowed to become well-established in 1981 and no data were collected. Beginning in 1982, the plots were mowed in the early spring of each year to remove any growth from the previous year and treated with fertilizers and herbicides as described. After all the grasses had headed, the plots were harvested with a flail harvester with a cutting height of $10 \mathrm{~cm}$. Forage samples for dry matter and quality analyses were handled as described for Exp. 1. First-cut harvests were made during the latter part of June at Mead and early July at Alliance. A second-cut was harvested at Mead the end of October 1982. There was insufficient regrowth at Alliance in both years for a regrowth harvest.

Data were analyzed using plot means for the 2 yr the plants were harvested because mean performance of the strains was the statistic of interest. Although the Alliance nursery had five replications, the first two blocks were damaged (by unknown factors) during the winter of 1982-1983 and were not usable for forage harvests in 1983 . The means reported for Alliance are for the three replications harvested in both 1982 and 1983.

\section{Experiment 3-Forage Composition and Digestibility of Forage Components}

In addition to the forage samples taken for the conventional IVDMD and protein tests, another set of samples was collected at the first forage harvest at Mead in 1983 for all six replications and was used to determine the fiber composition and digestibility of these grasses. These samples were collected fresh, frozen, and stored at $-17^{\circ} \mathrm{C}$ until the winter of 1983-1984 when they were freeze-dried and ground to pass a $1-\mathrm{mm}$ screen. One set of these samples was analyzed using the sequential detergent analyses system of Van Soest and Robertson (1980), while the other set was incubated in rumen fluid at $39^{\circ} \mathrm{C}$ for $48 \mathrm{~h}$. Then the residue was analyzed using the sequential detergent analyses system. This procedure makes it possible to determine the cell wall (CW), hemicellulose (HC), cellulose (CEL), and lignin (LIG) content of the forage, and the in vitro digestibility of these forage fractions. The IVDMD of these samples was also determined (Tilley and Terry, 1963). In the in vitro analyses, $0.5 \mathrm{-g}$ samples were incubated in $50-\mathrm{mL}$ culture tubes with $24 \mathrm{~mL}$ McDougall's buffer (McDougall, 1948) and $6 \mathrm{~mL}$ strained rumen fluid. The rumen fluid was obtained from a rumen fistulated steer maintained on grass-alfalfa hay after a 16 -h fast. The culture tubes were centrifuged $(3000 \times \mathrm{g}, 20 \mathrm{~min})$ and the supernatant discarded prior to the analyses of the residual fiber. The in vitro fermentations were conducted on duplicate samples on two separate occasions. Cell wall (CW), HC, CEL, and LIG were calculated from neutral detergent fiber, acid detergent fiber, and acid detergent lignin (72\% $\left.\mathrm{H}_{2} \mathrm{SO}_{4}\right)$ values $(\mathrm{CW}=$ neutral detergent residue; $\mathrm{HC}=$ neutral detergent residue minus acid detergent residue; $\mathrm{CEL}=$ acid detergent residue minus acid detergent lignin; $\mathrm{LIG}=$ acid detergent lignin minus ash). The in vitro digestibility of the components was calculated as follows: [( $\mathrm{mg}$ of fiber fraction in forage sample) - (mg of fiber fraction remaining after in vitro fermentation)]/(mg of fiber fraction in forage sample) $\times 1000$.

\section{RESULTS AND DISCUSSION}

\author{
Experiment 1-Genetic Variability in the RS \\ Population
}

There was considerable variability among the RS lines for all traits evaluated except for first-harvest IVDMD (Tables 2 and 3). Broad-sense heritabilities were $>0.5$ for all traits except for IVDMD and dry matter content (Table 3). Asay and Hanson (1984) previously reported significant genetic variability in an advanced RS population when evaluated in Utah for seed yield, forage yield, and rhizomatous spread. Although the RS population has a narrow genetic base (Dewey, 1976), both the results of this study and the results of Asay and Hanson (1984) indicate that the forage yield of this population could be improved by breeding. The results of the protein analyses also indicate that breeding could improve the protein content of the forage of the RS population. The results of this study indicate, however, that the potential of improving the IVDMD of the RS population appears limited unless additional germplasm is introgressed into it using methods suggested by Asay and Hanson (1984).

First-cut traits were correlated using 2-yr means for the RS lines. The only correlation coefficients that were significant were protein and dry matter percentages $(r$ $=-0.56^{* *}$, significant at the 0.01 probability level) and protein percentage and heading date $\left(r=0.49^{* *}\right)$. Consequently, selection for forage yield in the RS population probably would not adversely affect the other traits.

Although this study indicated that it should be possible to improve the forage yield of the RS population by breeding, it also demonstrated that in a spaceplanted evaluation nursery in eastern Nebraska, the highest yielding RS lines produced only about half as much forage as intermediate wheatgrass for both the first and second harvests (Table 2).

\section{Experiment 2-Sward Evaluation of RS and RD Hybrids}

This study was initiated to validate the yield results of Exp. 1 and to compare the RS and RD hybrids with crested and intermediate wheatgrass for their productivity under sward conditions in two environmental regimes of the Central Great Plains. Mead and Alliance represent the opposite ends of the east-to-west climatic continuum that exists in this area. Intermediate wheatgrass is recommended for range and pasture seedings throughout the Central Great Plains, whereas crested wheatgrasses are typically recommended for only the western third of this area (represented by Alliance) because they lack the yield potential of intermediate wheatgrass under the higher precipitation of the eastern two-thirds of this area (represented by Mead).

Although the sward plots were established by transplanting seedlings, the yield of intermediate and crested wheatgrass were similar to yields obtained previously in seeded yield tests. At Mead, intermediate wheatgrass had significantly higher yields and IVDMD (except for RS-1) than the other grasses for both harvests (Table 4). The RS hybrids were similar to the crested 
Table 2. Means and ranges for quackgrass $\times$ bluebunch wheatgrass intergeneric hybrids evaluated in a space-planted nursery at Lin coln, NE, in 1980 and 1981.

\begin{tabular}{|c|c|c|c|c|c|c|c|c|c|c|c|c|c|c|c|c|}
\hline \multirow[b]{3}{*}{ Strain } & & \multirow{3}{*}{\multicolumn{2}{|c|}{ Statistic }} & \multirow[b]{3}{*}{$n$} & \multicolumn{12}{|c|}{ Traits } \\
\hline & & & & & \multicolumn{6}{|c|}{ Harvest 1} & \multicolumn{6}{|c|}{ Harvest $2 \dagger$} \\
\hline & & & & & $\begin{array}{l}\text { Heading } \\
\text { date }\end{array}$ & Yield & & $\begin{array}{l}\text { Dry } \\
\text { atter }\end{array}$ & VDMD & Prote & Yie & eld & $\underset{\text { matter }}{\text { Dry }}$ & IVDMD & & otein \\
\hline & & & & & days & g/plant & \multicolumn{3}{|c|}{$\longrightarrow \mathrm{g} \mathrm{kg}^{-1}$} & 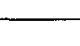 & \multicolumn{2}{|c|}{ g/plant } & $\longrightarrow$ & $-\mathrm{g} \mathrm{kg}^{-1}$ & \\
\hline \multicolumn{2}{|c|}{$\begin{array}{l}\text { Quackgrass } \times \text { bluebunch } \\
\text { wheatgrass hybrids }\end{array}$} & \multicolumn{2}{|c|}{$\underset{\text { Range }}{\bar{X}}$} & 28 & $\begin{array}{ll}151 & 1 \\
148-156\end{array}$ & $\begin{array}{l}174 \\
108-235\end{array}$ & \multicolumn{2}{|c|}{$\begin{array}{l}400 \\
378-430\end{array}$} & $\begin{array}{l}526 \\
501-561\end{array}$ & $\begin{array}{l}134 \\
116-147\end{array}$ & \multicolumn{2}{|c|}{$\begin{array}{l}64 \\
28-114\end{array}$} & $\begin{array}{l}483 \\
410-538\end{array}$ & $\begin{array}{l}389 \\
337-481\end{array}$ & \multicolumn{2}{|c|}{$\begin{array}{l}140 \\
131-151\end{array}$} \\
\hline Quackgrass & & $\bar{X}$ & & 2 & 152 & 159 & \multicolumn{2}{|c|}{400} & 24 & 125 & \multicolumn{2}{|l|}{50} & 43 & 496 & \multicolumn{2}{|c|}{146} \\
\hline \multicolumn{2}{|l|}{$\begin{array}{l}\text { Slate intermediate } \\
\text { wheatgrass }\end{array}$} & $\bar{x}$ & & 1 & 152 & 415 & \multicolumn{2}{|c|}{359} & 15 & 125 & \multicolumn{2}{|l|}{174} & 350 & 546 & \multicolumn{2}{|l|}{160} \\
\hline $\begin{array}{l}\mathrm{LSD}_{0.05} \\
F \text { for strains }\end{array}$ & & & & & $\begin{array}{l}3 \\
3.86 * *\end{array}$ & 60 & \multicolumn{2}{|c|}{$\begin{array}{l}25 \\
2.89^{* *}\end{array}$} & $\begin{array}{l}\text { NS } \\
1.36\end{array}$ & $\begin{array}{l}14 \\
2.33^{*}\end{array}$ & \multicolumn{2}{|c|}{$\begin{array}{l}55 \\
2.42 * *\end{array}$} & $\begin{array}{l}54 \\
3.75^{* *}\end{array}$ & $\begin{array}{l}79 \\
3.08 \text { * }\end{array}$ & \multicolumn{2}{|c|}{$\begin{array}{l}12 \\
* \quad 2.10^{* *}\end{array}$} \\
\hline \multicolumn{14}{|c|}{ *,** Indicates significance at the 0.05 and 0.01 levels of probability, respectively. NS indicates nonsignificance. } & \multicolumn{3}{|c|}{$\dagger 1980$ data only. } \\
\hline & & & & & & & & & Traits & & & & & & & \\
\hline & & Head & ing d & & & Yield & & & VDMD & & & rotein & & Dry & matter & \\
\hline Source & df & MS & vC & $\pm \mathrm{SE}$ & MS & $\mathrm{VC} \pm$ & $=\mathbf{S E}$ & MS & $\mathrm{VC}=$ & $\mathrm{SE}$ & MS & VC & $\pm \mathrm{SE}$ & MS & $\mathrm{VC}=$ & $\pm \mathrm{SE}$ \\
\hline & & 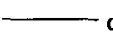 & ays - & 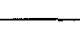 & $\longrightarrow \mathrm{g} /$ & /plant & {[} & & & & & $\mathrm{g} \mathrm{kg}^{-1}$ & . & & & \\
\hline $\begin{array}{l}\text { Replicates (R) } \\
\text { Strains (S) } \\
\mathbf{R} \times \mathbf{S}\end{array}$ & $\begin{array}{r}3 \\
27 \\
81\end{array}$ & $\begin{array}{l}45.7 \\
27.0^{* *} \\
7.2\end{array}$ & $\begin{array}{l}0.6 \\
2.4 \\
0.9\end{array}$ & $\begin{array}{l}0.5 \\
0.9 \\
0.7\end{array}$ & $\begin{array}{l}3749 \\
9288^{* *} \\
2616\end{array}$ & $\begin{array}{r}-14 \\
835 \\
373\end{array}$ & $\begin{array}{r}61 \\
317 \\
250\end{array}$ & $\begin{array}{r}2444 \\
1207 \\
726\end{array}$ & $\begin{array}{r}-20 \\
40 \\
69\end{array}$ & $\begin{array}{l}47 \\
50 \\
72\end{array}$ & $\begin{array}{l}263 \\
421^{*} \\
164\end{array}$ & $\begin{array}{r}3 \\
30 \\
2\end{array}$ & $\begin{array}{r}3 \\
16 \\
18\end{array}$ & $\begin{array}{r}217 \\
1245 \\
812\end{array}$ & $\begin{array}{r}-14 \\
63 \\
146\end{array}$ & $\begin{array}{r}8 \\
47 \\
75\end{array}$ \\
\hline $\begin{array}{l}\text { Years }(\mathrm{Y}) \\
\mathrm{Y} \times \mathrm{S} \\
\mathrm{Y} \times \mathrm{R} \\
\mathrm{Y} \times \mathrm{S} \times \mathrm{R}\end{array}$ & $\begin{array}{r}1 \\
27 \\
3 \\
81\end{array}$ & $\begin{array}{c}399.1^{* *} \\
6.4 \\
11.1 \\
5.4\end{array}$ & $\begin{array}{l}3.4 \\
0.2 \\
0.2 \\
5.4\end{array}$ & $\begin{array}{l}2.9 \\
0.5 \\
0.2 \\
0.8\end{array}$ & $\begin{array}{c}170256^{* *} \\
1865 \\
3811 \\
1870\end{array}$ & $\begin{array}{r}1486 \\
1 \\
69 \\
1870\end{array}$ & $\begin{array}{r}1241 \\
142 \\
87 \\
290\end{array}$ & $\begin{array}{c}133100^{* *} \\
749 \\
3400^{* *} \\
588\end{array}$ & $\begin{array}{r}1157 \\
40 \\
100 \\
588\end{array}$ & $\begin{array}{r}972 \\
23 \\
77 \\
91\end{array}$ & $\begin{array}{c}7644 * * \\
181 \\
77 \\
160\end{array}$ & $\begin{array}{r}68 \\
5 \\
-3 \\
160\end{array}$ & $\begin{array}{r}56 \\
13 \\
2 \\
25\end{array}$ & $\begin{array}{c}539271 * * \\
449 \\
681 \\
520\end{array}$ & $\begin{array}{r}4809 \\
-18 \\
6 \\
520\end{array}$ & $\begin{array}{r}3931 \\
36 \\
16 \\
81\end{array}$ \\
\hline Heritability $\left(H^{2}\right) \dagger$ & & & 0.70 & & & 0.72 & & 0.26 & & & 0.55 & & & 0.38 & & \\
\hline
\end{tabular}

*** Indicates significance at the 0.05 and the 0.01 levels of probability, respectively.

$\dagger H^{2}=\sigma_{g}^{2} /\left(\sigma_{g}^{2}+\sigma_{g r}^{2} / r+\sigma_{g y}^{2} / y+\sigma_{g y r}^{2} / r y\right)$, where $g=$ strains, $r=$ reps, and $y=$ years.

Table 4. Means of wheatgrass cultivars and intergeneric hybrids grown in sward nurseries at Mead and Alliance, NE. $\dagger$

\begin{tabular}{|c|c|c|c|c|c|c|c|c|c|}
\hline \multirow[b]{2}{*}{ Strain } & \multicolumn{5}{|c|}{ Harvest 1} & \multicolumn{4}{|c|}{ Harvest $2 \ddagger$} \\
\hline & Heading date & Yield & IVDMD & Protein & Dry matter & Yield & IVDMD & Protein & Dry matter \\
\hline & & $\mathbf{M g ~ h \mathbf { a } ^ { - 1 }}$ & & $\mathbf{g} \mathbf{k g}^{-1}$ & - & Mg ha $\mathbf{a}^{-1}$ & & $\mathbf{g ~ k g}^{-1}$ & 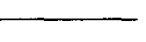 \\
\hline \multicolumn{10}{|c|}{ Mead } \\
\hline RS 1 & 158 & 4.7 & 535 & 93 & 333 & 1.2 & 571 & 131 & 426 \\
\hline RS 2 & 158 & 4.9 & 525 & 86 & 346 & 1.2 & 554 & 132 & 420 \\
\hline RD & 158 & 3.8 & 531 & 87 & 343 & 0.9 & 572 & 135 & 389 \\
\hline Slate & 166 & 7.4 & 548 & 87 & 303 & 2.0 & 629 & 135 & 373 \\
\hline Ruff & 158 & 4.9 & 520 & 87 & 383 & 1.1 & 591 & 131 & 377 \\
\hline Nordan & 157 & 4.7 & 515 & 87 & 371 & 0.6 & 599 & 142 & 418 \\
\hline $\operatorname{LSD}_{0.08}$ & 1 & 0.6 & 17 & NS & NS & 0.3 & 4 & NS & NS \\
\hline CV \% & 0.6 & 10.3 & 2.8 & 7.3 & 7.3 & 23.0 & 5.8 & 7.4 & 10.2 \\
\hline \multicolumn{10}{|c|}{ Alliance } \\
\hline RS 1 & 164 & 4.2 & 576 & 87 & 558 & & & & \\
\hline RS 2 & 163 & 4.1 & 569 & 82 & 534 & & & & \\
\hline RD & 166 & 3.0 & 554 & 90 & 560 & & & & \\
\hline Slate & 174 & 4.9 & 629 & 85 & 515 & & & & \\
\hline Ruff & 159 & 5.0 & 581 & 83 & 590 & & & & \\
\hline Nordan & 154 & 4.7 & 552 & 85 & 570 & & & & \\
\hline $\mathrm{LSD}_{0.06}$ & 4 & 1.3 & 23 & NS & 32 & & & & \\
\hline $\mathrm{CV} \%$ & 1.7 & 16.8 & 2.2 & 6.8 & 3.1 & & & & \\
\hline
\end{tabular}

$\dagger$ Data analyzed using plot means over years.

$\ddagger 1982$ data only.

wheatgrasses for first-harvest forage yield and IVDMD. The RS hybrids had higher second-harvest yields at Mead than Nordan. The RD hybrid had lower forage yields than intermediate and crested wheatgrasses at both locations for the first harvest demonstrating that at this stage of development, it lacks the yield potential of these grasses in the Central Great Plains. At Alli- ance, the yields of intermediate and the crested wheatgrasses were similar. The yields of the RS hybrids were lower than the crested and intermediate wheatgrasses at Alliance but these differences were not significant. Intermediate wheatgrass also had the highest IVDMD at Alliance. Although significant differences were not observed, RS-1 had higher IVDMD means at both 
locations than RS-2, and Ruff had higher first-harvest IVDMD means than Nordan. There was no difference among the grasses for forage protein content at either location.

Intermediate wheatgrass may have been higher in digestibility than the other grasses because of its later maturity. In the Central Great Plains, the wheatgrasses in this study initiate spring growth about the same time and they would be grazed during the same time periods. At comparable stages of maturity, intermediate wheatgrass may not be higher in digestibility than the other wheatgrasses, but during the period of use by grazing livestock it would provide more digestible forage particularly during late spring and early summer. Warm-season grasses or native range are normally used for summer grazing in the Central Great Plains. Our results thus indicate that intermediate wheatgrass is clearly the superior forage grass in terms of forage yield and quality as measured by IVDMD in the eastern part of the Central Great Plains. In the western part of this area, intermediate wheatgrass and crested wheatgrass are equal or superior to the RS hybrids in forage yield, and intermediate wheatgrass has more digestible forage as measured by IVDMD.

\section{Experiment 3-Forage Composition and Digestibility of Forage Components}

The composition of the dry matter of grasses changes as they mature with grasses decreasing in digestibility with maturity (Wilman et al., 1977). In the sward plots at Mead, this diverse set of wheatgrasses headed at about the same time, with the exception of intermediate wheatgrass, which headed about a week later than the other grasses. Because they were all grown in the same environment and were all similar in maturity, the forage samples from these grasses provided an opportunity to determine if there were differences among wheatgrasses for forage fiber composition and the digestibility of fiber components.

The fiber composition of these grasses was expressed both as grams per kilogram of dry matter and as grams per kilogram of cell wall (Table 5). Cell wall (CW) content of the grasses did not differ greatly except for the RD hybrid for which CW content was significantly lower than for the other strains. Although Slate was phenologically about 7 days later in maturity than the other grasses, morphologically it was of similar maturity if $\mathrm{CW}$ content is used as the measure of maturity. The amount of the cell wall that was hemicellulose $(\mathrm{H})$ was variable, but Ruff crested wheatgrass had higher HC content when expressed on either a dry weight or cell wall basis than the other grasses. Ruff had the lowest cellulose (CEL) fraction when expressed as grams per kilogram of cell wall. Slate intermediate wheatgrass and the RD hybrid had higher CEL content in their CW than the other grasses, although this difference was not significant for Slate. Lignin (LIG) content of the forages was extremely variable, with the crested wheatgrasses highest, the RD hybrid intermediate, and Slate intermediate wheatgrass and the RS hybrids lowest in LIG content.

Although CW content of the grasses did not generally differ (with the exception of the RD hybrid), digestibility of the $\mathrm{CW}$ differed among the grasses (Table 5). The CW of Slate intermediate wheatgrass was significantly more digestible than all the other grasses. Ruff crested wheatgrass had a more digestible $\mathrm{CW}$ than Nordan and the RS and RD hybrids but these differences were not significant. Digestibility of HC varied with the RS and RD hybrids tending to be lower and the intermediate wheatgrass highest in digestibility. The CEL digestibility of intermediate wheatgrass was the highest with considerable overlap in CEL digestibility among the other grasses. Surprisingly, the grasses with the highest LIG content also had the most digestible

Table 5. Forage composition of wheatgrass cultivars and intergeneric hybrids grown at Mead, NE, and the in vitro digestibility of the forage dry matter and cell wall components. $\dagger$

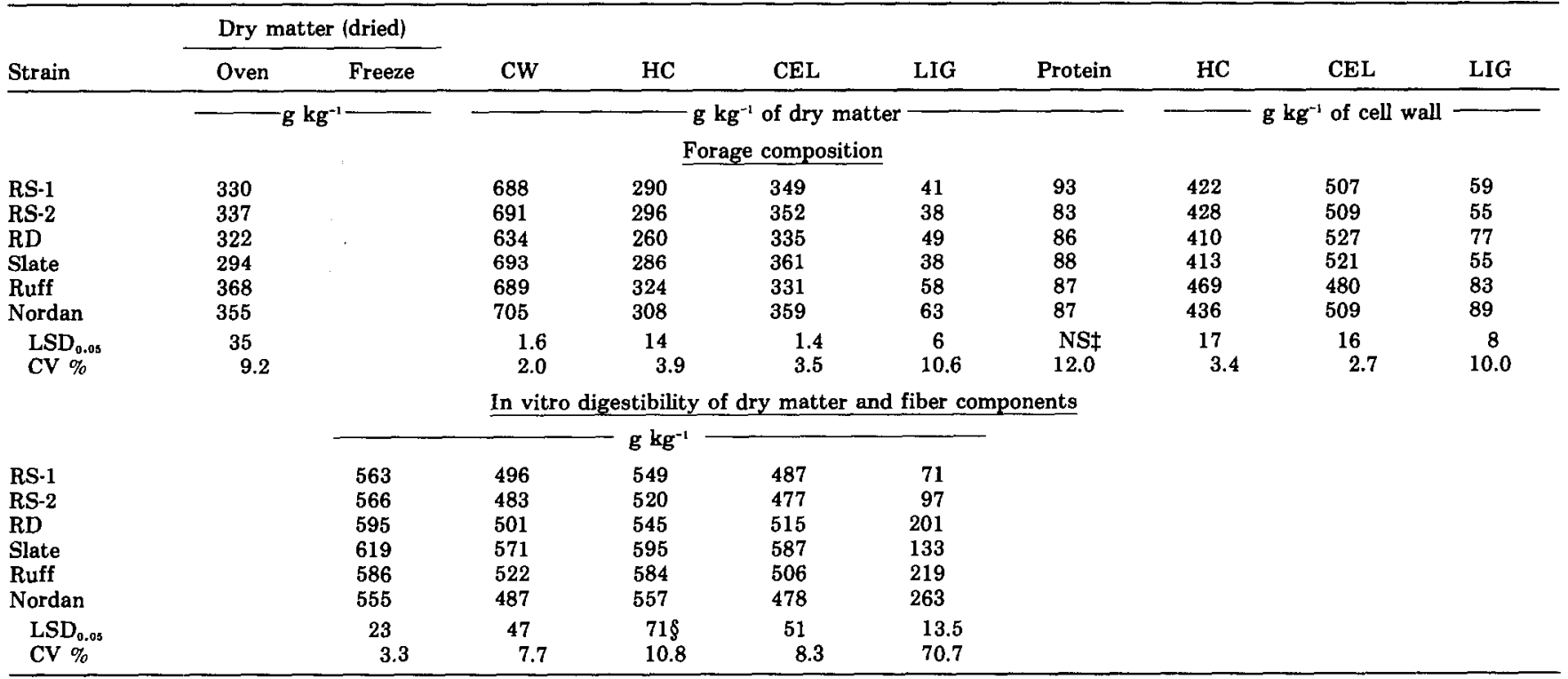

$\dagger \mathrm{DM}=$ dry matter, $\mathrm{CW}=$ cell wall, $\mathrm{HC}=$ hemicellulose, $\mathrm{CEL}=$ cellulose, $\mathrm{LIG}=$ lignin .

I Indicates nonsignificance of the $F$ statistic in analysis of variance at the 0.05 level of probability.

$\S F$ statistic in analysis of variance was significant at the 0.06 level of probability. 
LIG fraction. Conversely, the strains that contained the least LIG had relatively undigestible LIG.

The results illustrate that while the $\mathrm{CW}$ content of these grasses did not, in general, differ widely, the composition of the $\mathrm{CW}$ was significantly different. With the exception of Slate intermediate wheatgrass, all the forages were similar in phenological maturity. Yet intermediate wheatgrass had the same quantity of $\mathrm{CW}$ as crested wheatgrass and RS hybrids. The RD hybrid had even less $\mathrm{CW}$ than intermediate wheatgrass. Slate also contained similar amounts of lignin to the RS hybrids. In addition to the variation found among the grasses for fiber composition, the grasses also differed for digestibility of these components. It is apparent that differences exist among wheatgrasses for both fiber composition and its digestibility. It is interesting to note that the lignin content of the RD hybrid is intermediate to that of the crested wheatgrasses and the RS hybrids but the digestibility of the lignin is very similar to that of the crested wheatgrasses. These results suggest that forage fiber content, composition, and digestibility of wheatgrasses are under genetic control.

\section{SUMMARY}

The yield of the RS hybrids could be improved by breeding to make them more competitive with intermediate and crested wheatgrasses. However, the same breeding effort could be used to improve both the yield and IVDMD of intermediate and crested wheatgrass. Lamb et al. (1984) and Vogel et al. (1986) have documented substantial genetic variability for both yield and IVDMD in the crested and intermediate wheatgrass complexes. Since genetic variability for IVDMD is currently lacking in the RS population, breeding work within the pure species would probably result in greater progress. White and Wight (1981) suggested that the most important forage traits of the wheatgrasses are yield and IVDMD. We concur that IVDMD is a better single measure of quality than composition fractions such as CW, HC, CEL, and LIG because these fractions can differ in digestibility as we have demonstrated. However, since noncell wall components of forage are virtually $100 \%$ digestible, IVDMD is actually mirroring $\mathrm{CW}$ digestibility. The procedure used in this study to determine digestibility of cell wall components could be effectively used within species to determine the cell wall source of genetic variability for dry matter digestibility.

The RS and RD intergeneric populations appear to have limited present or future value as forage grasses in the Central Great Plains based on these small plot studies. Desirable traits such as the ability to persist under grazing pressure have not been evaulated, however. Intergeneric hybrids may have potential as tools for investigating genetic control of fiber composition and digestibility level in the wheatgrasses since there are apparently major differences among wheatgrass genomes for fiber composition and digestibility.

\section{REFERENCES}

Asay, K.H., and D.R. Dewey. 1981. Registration of Agropyron repens $\times$ A spicatum germplasms RS-1 and RS-2. Crop Sci. 21:351. --, and W.T. Hansen II. 1984. Prospects for genetic improvement in the quackgrass $X$ bluebunch wheatgrass hybrid. Crop Sci. 24:743-745.

Association of Official Agricultural Chemists (AOAC). 1960. Official methods of analyses of the A.O.A.C. 9 th ed. Association of Official Agricultural Chemists, Washington, DC.

Barkworth, M.E., and D.R. Dewey. 1985. Genomically based genera in the perennial triticeae of North America: Identification and membership. Am. J. Bot. 72(5):767-776.

Dewey, D.R. 1961. Hybrids between Agropyron repens and Agropyron desertorum. J. Hered. 52:13-21.

---. 1976. Derivation of a new forage grass from Agropyron repens $\times$ Agropyron spicatum hybrids. Crop Sci. 16:175-180.

-_- 1980. Quackgrass-a species with unusual plant breeding potential. Agron. Abstr. American Society of Agronomy, Madison, WI, p. 53 .

- 1984 . The genomic system of classification as a guide to intergeneric hybridization with the perennial Triticeae. p. 209-279. In J.P. Gustafson (ed.) Gene manipulations in plant improvement. 16th Stadler Genetics Symp., Columbia, MO. 19-21 Mar. Plenum Press, New York.

Gomm, F., and W. Horton. 1983. Testing new grasses for rangelands. Utah Sci. 44:44-49.

Hitchcock, A.S. 1951. Manual of grasses of the United States. 2nd ed. Agnes Chase (ed.) USDA Misc. Publ. 200. U.S. Government Printing Office, Washington, DC.

Lamb, J.F.S., K.P. Vogel, and P.E. Reece. 1984. Genotype and genotype $X$ environment interaction effects on forage yield and quality of crested wheatgrass. Crop Sci. 24:559-564.

Launchbaugh, J.L. (ed.) 1966. A stand establishment survey of grass plantings in the Great Plains. Nebr. Agric. Exp. Stn. Great Plains Council Pub. no. 23.

McDougall, E.I. 1948. Studies on ruminant saliva. I. The composition and output of sheep's saliva. Biochem. J. 43:99-109.

National Oceanic and Atmospheric Administration. 1979-1983. Climatological data annual summaries 1979, 1980, 1981, 1982, and 1983. Asheville, NC.

Perez-Trejo, F., D.D. Dwyer, and K.H. Asay. 1979. Forage yield, phenological development, and forage quality of an Agropyron repens $\times A$. spicatum hybrid. J. Range Manage. 32:387-390.

Snedecor, G.W., and W.G. Cochran. 1967. Statistical methods. 6th ed. Iowa State University Press, Ames.

Tilley, J.A., and R.A. Terry. 1963. A two-stage technique of the in vitro digestion of forage crops. J. Br. Grassl. Soc. 18:104-111.

Van Soest, P.J., and J.B. Robertson, 1980. System of analyses for evaluating fibrous feeds. p. 49-60. In W.J. Pigden, et al. (ed.) Standardization of analytical methodology for feeds. Int. Development Res. Ctr., Ottawa, Canada. Pub. IDRC-134e.

Vogel, K.P., P.E. Reece, and J.F.S. Lamb. 1986. Genotype and genotype $X$ environmental interaction effects for forage yield and quality of intermediate wheatgrass. Crop Sci. 26:653-658.

White, L.M., and J.R. Wight. 1981. Seasonal dry matter yield and digestibility of seven grass species, alfalfa, and cicer milkvetch in eastern Montana. Agron. J. 73:457-462.

Wilman, D., M. Daly, A. Koocheki, and A.B. Lwoga. 1977. The effect of interval between harvests and nitrogen application on the proportion and digestibility of cell wall, cellulose, hemicellulose, and lignin and on the proportion of lignified tissue in leaf cross sections in two perennial ryegrass varieties. J. Agric. Sci. 89:53-63. 